\title{
An Example of Military Engineering in 16th Century: The Star Fort of Turin
}

\section{Amelia Carolina Sparavigna}

Department of Applied Science and Technology, Politecnico di Torino, Torino, Italy

\begin{abstract}
Star forts were the fortifications composed of many triangular bastions, created from 1520s, to replace those of the medieval age, and able of resisting the gunpowder weapons. These fortifications were also defined as "trace italienne", because they were first planned and built in Italy. Some of these forts are still existing today, many had been destroyed or dismantled in the past. Here we will discuss the case of one of them, cancelled by an urban planning for expanding the town. It is the Citadel of Turin, of which only the Mastio survived.
\end{abstract}

Keywords: History of Engineering, History of Science

\section{Introduction}

Gunpowder was invented in the 9th century in China [1]. After the earliest gunpowder weapons were made there, such weapons began appearing in the Muslim world, Europe and India. The earliest Western accounts of gunpowder seem those written by Roger Bacon, English philosopher and Franciscan friar, in the 13th century. Examples of its use for weapons are illustrated in one of the earliest Renaissance technological treatise, the "Bellicorum Instrumentorum Liber" of Giovanni Fontana, engineer [2,3]. After the developments of such weapons, the fortifications of the medieval period became vulnerable to cannon fire, and new fortifications were created. They were the star forts. The star fort is the fortification typical of the period when cannons dominated battlefields. This fortification was also known as "trace italienne", or "Italian style", because it first arose in Italy. The appearance of such fortresses, beginning in the $1520 \mathrm{~s}$, ended the brief era for wall-shattering cannons [4]. Then, as in any dialectic process appearing during historical periods, the improvements in siege techniques involved progresses in building fortifications and vice versa [5,6]. The invasion of Italy by Charles VIII of France in 1494, with 40 cannons on carriages pulled by horses, demonstrated the power of artillery but originated in the early 16th century, the new fortification design. In this manner, the impact of the artillery revolution was dampened by the creation of the new fortresses, but it had a consequence: the supremacy gained by owning an efficient artillery strengthened the royal authorities existing in late fifteenth century [7].

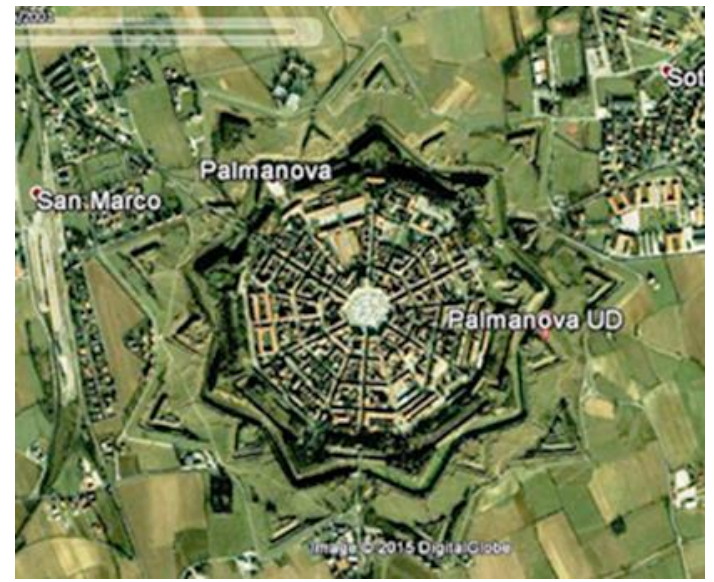

Figure 1: Palmanova, a town planned like a star fort, seen from satellites (Courtesy: Google Earth).

The reasons for the success of the "trace italienne" are well explained in Ref.8. Many towns were then equipped, with huge structures made of bastions, glacises and ditches. Some towns were also planned and created according to the new "style", such as the town of Palmanova in Italy (Fig.1). Today, some of these fortifications are still existing in Europe and around the world. Many had been destroyed or dismantled in the past. Here, we will show the case of a star fort that was cancelled by an urban planning for expanding the town. It is the Citadel of Turin, of

This article is published under the terms of the Creative Commons Attribution License 4.0

Author(s) retain the copyright of this article. Publication rights with Alkhaer Publications.

Published at: http://www.ijsciences.com/pub/issue/2015-12/

DOI: 10.18483/ijSci.880; Online ISSN: 2305-3925; Print ISSN: 2410-4477 
which only the Keep, the "Mastio", survived. Before talking of it, let us shortly remember the role of scientists and engineers in the studies of artillery and for planning fortifications.

\section{Scientists and artillery}

Ballistics as a science had an extraordinary development when the firearms were introduced into the warfare of Western Europe. Not surprisingly, the greatest scientists and mathematicians of time were hired by landlords and governors as consultants for artillery, to solve the problems related to the motion of projectiles. Among them, we find Leonardo da Vinci, Galileo, Tartaglia and, after, Isaac Newton and Huygens [9]. For instance, the Italian principality of Verona hired the mathematician Niccolò Tartaglia (1499-1557), who was asked to solve a simplesounding problem: At what angle must a gun be held to fire the farthest? [10]. Tartaglia wrote a book on this subject; after some firing tests to determine this angle, he discovered that it was near 45 degrees. As told in [11], an interesting observation is that Tartaglia's result is true only when, on the bullet, the aerodynamic forces are negligible. "With today's guns, the firing elevation angle which maximizes range is nearer 30 degrees than 45 , because (today) trajectory shapes are determined almost completely by aerodynamic forces at velocity levels achieved" [11]. This explains Tartaglia's result that had an important significance in Galileo's theoretical work, which took place nearly a century after Tartaglia. Galileo too acted as a consultant to the Venetian Arsenal [12].

\section{Italian engineers and the success of new fortifications}

After the development of new weapons, the defensive works gained a new form, that of starred structures. Forts became very flat, composed of many triangular bastions, which can cover each other. The development of this new style of fortresses was due to many Italian architects and engineers. Even Michelangelo was involved for planning some defensive works for Florence with the new style.

After the works of Sangallo engineers, Antonio the Elder (1455-1534) and Antonio the Younger (1484$1546)$, more refined structures were developed in 16th century by Baldassare Peruzzi (1481-1536) and Vincenzo Scamozzi (1548-1616) [8]. Scamozzi was the architect that planned Palmanova (see Figure 1) [13].

The design spread out of Italy and was employed heavily throughout Europe, with Italian engineers hired to build the new fortifications for the following three centuries. Among these engineers, let us remember also Giovan Giacomo Paleari Fratino (1520-1586), known as the "Fratino", the Little Friar, who served Spanish emperors [14]. He is known for having designed the first Martello tower as well as many other fortifications. The brothers of him, Bernardino and Giorgio, followed the same trade.

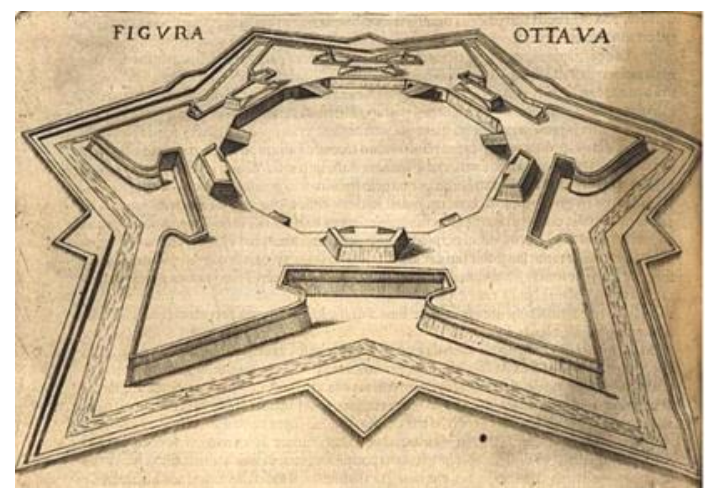

Figure 2: A star fort from [17].

If we want to have an idea of artillery at the end of the sixteenth century we can read the "Prattica Manuale dell'Artiglieria", composed by Luigi Colliado (Luis Collado), published in 1606 [15], where he describes the motion of projectiles according to the doctrine expounded by Tartaglia, and also the "Corona, e Palma Militare di Artiglieria, et Fortificationi" by Alessandro Capo Bianco Vincentino [16] and the "Corona Imperiale" by Pietro Sardi [17].

As told in [18], besides planning fortresses, the Italian engineers published also many books illustrating them. Among them we find: "Giovan Francesco Fiamelli Fiorentino, Giovan Battista Porta Napoletano, Vincenzo Scamozzi Architetto Veneto, Pietro Sardi Romano, Pietro Antonio Barca Milanese Ingegnere del Re di Spagna, Matteo Oddi, il Cavaliere Francesco Tensini da Crema, ..." and many others whose names we find in the given reference. A detailed discussion on the cultural and social effect of the Renaissance Italian military engineer is given in [19].

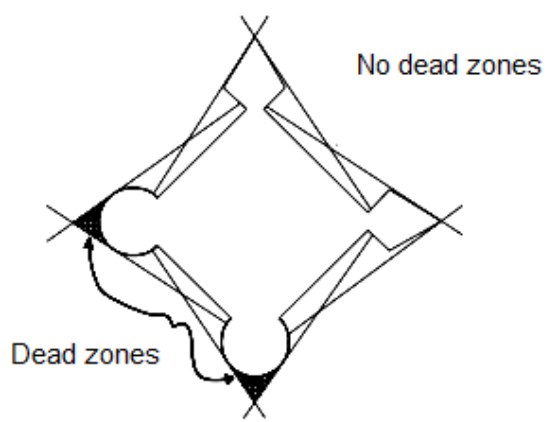

Figure 3: Defending fire in the case of round and star shapes.

Just to understand the reason of the star shape, let us look at Figure 3 [8]. The rounded shape, that had been dominant for the design of turrets created "dead space", or zones, which were unreachable by 
defending fire. To prevent this, the structures having a round or square shape were extended into diamondshaped points. Moreover, ditches and walls directed attacking troops into carefully constructed grounds where the defensive fire neutralized them [8]. Fortifications of this type continued to be effective until the attacking troops were armed only with cannons. In fact, the cannons were inflicting damage from the impact of their solid shots. While only low explosives such as black powder were available [8], explosive shells were ineffective against such fortifications. The development of new explosives, and the consequent increase in the power of explosive shells rendered the geometry of star forts irrelevant. According to [20], the appearance of the "trace italienne" and the difficulty of taking such fortifications, resulted in a profound change in military strategy [8]. The new forts required an increase in army sizes to invest them, and therefore, the existence or absence of the "trace italienne" in a given area, shaped the geography of the military strategy in the early modern period [20]. Therefore, the military revolution, due to a radical change in military strategy and tactics of the early modern Europe [7], had huge geopolitical consequences for European governments. We can argue that, since a large army was necessary for the modern war, this army could had been supported only by a relatively large country. In the early modern age then, we can find the origin of the European modern nations. Italy, in fact, originated also from the Piemontese army of the Duchy of Savoy, which was shaped by the military revolution. Let us then consider the case of Turin and its Citadel, which was able withstanding to many sieges, in particular that of 1706, "annus horribilis" for Louis XIV of France [21,22].

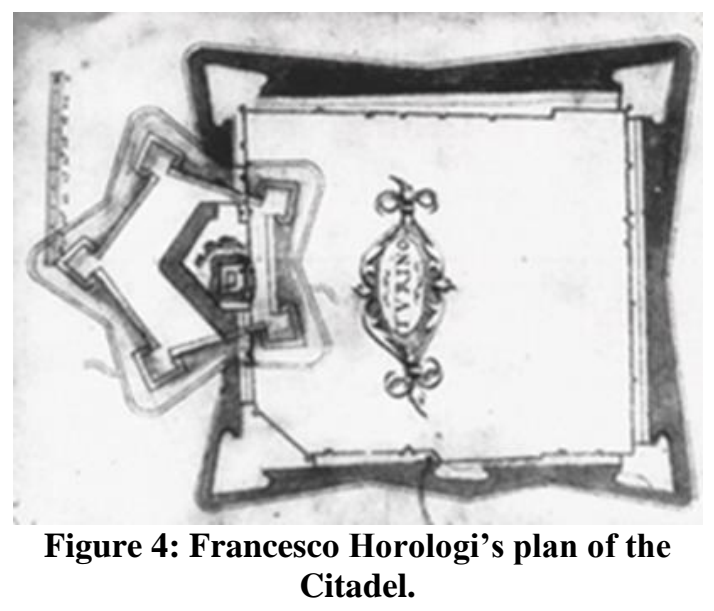

Turin and the Citadel

Torino is a town that had origin two thousand years ago, in a Roman "castrum", a Roman military defensive position. The planning is typical of a Roman town [23-26]. As a classic castrum, Turin has a square layout, which remained almost unchanged, complete with its ancient walls, for centuries both during the domination of Lombards and Franks. The town remained the same during the middle ages [27]. It started changing in the fifteenth century, when the Savoy dukedom achieved the unification of Piedmont and began consolidating its importance. Then, when in 1559, after the Cateau - Cambresis treatise, Emanuele Filiberto, duke of Savoy, chose Turin as the capital of his State, he found a walled medieval town. Due to the necessity of protecting his capital from modern weapons, in 1564, the duke charged the architects Francesco Horologi (o Orologi) from Vicenza and Francesco Paciotto (1521-1591) from Urbino of planning a huge pentagonal citadel at the south-west corner of Turin [28]. Francesco Horologi was among the most famous engineers in Europe. He served the Republic of Venice and the King of France (in the Figure 4, his plan for the Citadel). With huge financial investments, works began in 1564 and ended in 1566. We can see Torino in 1572, in a drawing of Giovanni Carracha, that is Jan Kraeck, (Figure 5, after references). We can see the star fort, the Citadel, with a pentagonal shape. After the Citadel of Turin, Paciotti worked for the citadel of Antwerp, with the same model [29].

While the Citadel prepared the city to withstand the new techniques of siege warfare, the rest of the modernization plan remained no more than a prospect. Some attempts were made to clean up the ancient center of the town. From the maps in the "Theatrum Sabaudiae" [30], we can see that the Citadel and the town was surrounded by a moat.

The Citadel such as the walls were conditioning elements for the town. The entire area occupied by the star fort was kept for years, even after the Napoleonic occupation and the demobilization of the several Savoy fortresses. In this manner, it was an obstacle for the expansion of Turin. It was around the middle of 19th-century, that it was decided its complete demolition. Only the Mastio, the Keep, later restored by Riccardo Brayda, is marking the old access to the Citadel [31].

Since the Citadel had been dismantled, we cannot see it in satellite maps, such as those of Google Earth for instance. However, using a map of 1640, and rotating it to have Via Garibaldi, originally the Decumanus Maximus of Turin, oriented as it is in a Google Map, the Citadel would appear like in the Figure 6 (after references). In the Figure 7 (after references), the map of Figure 6 is adapted to a satellite view of Turin. We can see that the Citadel was protecting the weakest corner of the town, the others being protected by two rivers, Po and Dora.

Many star forts are visible in the satellite images of Google Earth. One in particular is interesting, which has the same pentagonal form and orientation of the 
Citadel of Turin. It is the Goryokaku, the star fort in Japanese city of Hakodate on the island of Hokkaido (Figure 8). Goryokaku means "five angle fortification" and was designed in 1855 by Takeda Hisaburo. It was built from 1857 to 1864 . Takeda designed it according to the "trace italienne" planning, having learned it from Dutch books brought into Nagasaki [32]. Let us conclude noting that, today, Goryokaku is a park, declared a Special Historical Site and is home to the Hakodate city museum.

\section{References}

1. Needham, J. (1974). Science and Civilisation in China: Military Technology: The Gunpowder Epic, Cambridge University Press

2. Sparavigna, A.C. (2013). Giovanni de la Fontana, Engineer and Magician, arXiv:1304.4588 [physics.hist-ph]

3. Battisti, E.; Saccaro Battisti, G. (1984). Le Macchine Cifrate di Giovanni Fontana: Con la Riproduzione del Cod. Icon. 242 della Bayerische Staatsbibliothek di Monaco di Baviera e la Decrittazione di Esso d del Cod. Lat. Nouv. Acq. 635 della Bibliothèque Nationale di Parigi. Milano Arcadia. ISBN 10: 8885684068, ISBN 13: 9788885684065

4. Showalter, D.E.; Astore, W.J. (2007). The Early Modern World, Greenwood Publishing Group. ISBN 10: 0313333122, ISBN 13: 9780313333125

5. Vv. Aa. (2015). Rivoluzione Militare, it.wikipedia.org/wiki/Rivoluzione_militare

6. Contamine, P. (1984). War in the Middle Ages, Oxford ISBN 10: 0631131426, ISBN 13: 9780631131427

7. Roberts, M. (1956). The Military Revolution, 1560-1660; An Inaugural Lecture Delivered Before the Queen's University of Belfast. M. Boyd, Belfast.

8. Vv. Aa. (2015). Star Fort, Wikipedia, https://en.wikipedia.org/wiki/Star_fort

9. Steele, B.D. (2005). The Heirs of Archimedes: Science and the Art of War through the Age of Enlightenment, MIT Press. ISBN 10: 026219516X, ISBN 13: 978-0262195164

10. Darling, D. (2006). Gravity's Arc: The Story of Gravity from Aristotle to Einstein and Beyond, John Wiley \& Sons. ISBN 10: 0471719897, ISBN 13: 978-0471719892

11. Vv. Aa. (2015). Historical Summary, www.exteriorballistics.com

12. Biagioli, M. (1994). Galileo, Courtier: The Practice of Science in the Culture of Absolutism, University of Chicago Press. ISBN 10: 0226045609, ISBN 13: 978-0226045603

13. Costanzo, D. (2015). What Architecture Means: Connecting Ideas and Design, Routledge. ISBN 10: 0415739047, ISBN 13: $978-0415739047$

14. Viganò, M. (2004). "El fratin mi ynginiero": i Paleari Fratino da Morcote Ingegneri Militari Ticinesi in Spagna (XVI XVII secolo), Edizioni Casagrande. ISBN 10: 8877134186, ISBN 13: 978-8877134189

15. Colliado, L. (1606). Prattica Manuale dell'Artiglieria, Dove si Tratta dell' Eccellenza, \& Origine dell'Arte Militare, e delle Machine Usate da gli Antichi. Girolamo Bordoni e Pietromartire Locarni Printers. DOI: 10.3931/e-rara-29014
16. Capo Bianco, A. (1647). Corona, e Palma Militare di Artiglieria, et Fortificationi. Impressum in Venetia apud Antonio Bariletti. DOI: 10.3931/e-rara-13781

17. Sardi, P. (1618). Corona Imperiale dell' Architettura Militare, Venezia, a Spese dell'Autore nella Stamperia di Barezzo Barezzi. DOI: 10.3931/e-rara-11727

18. Marini, L. (1801). Saggio Istorico ed Algebraico sui Bastioni, Lazzarini. Available from https://books.google.it/

19. Carter, B.M. (2013). Defending Renaissance Italy: The Innovative Culture of Italian Military Engineers. Available at http://scholarworks.gsu.edu/cgi/viewcontent.cgi?article=1064 \&context=history_theses

20. Parker, G. (1976). The "Military Revolution," 1560-1660 - a Myth? The Journal of Modern History, 48(2):196-214. DOI $10.1086 / 241429$

21. Vv. Aa. (2015). Siege of Turin, https://en.wikipedia.org/wiki/Siege_of_Turin

22. Lynn, J.A. (1999). The Wars of Louis XIV, 1667-1714, Longman. ISBN 10: 0582056292, ISBN 13: 978-0582056299

23. Haverfield, F. (1913). Ancient Town-Planning, Oxford Clarendon.

24. Sparavigna, A.C. (2012). The Orientation of Julia Augusta Taurinorum (Torino), arXiv:1206.6062 [physics.pop-ph].

25. Sparavigna, A.C. (2012). The Orientation of Trajan's Town of Timgad, arXiv:1208.0454 [physics.hist-ph].

26. Sparavigna, A.C. (2014). Solstices at the Hardknott Roman Fort. PHILICA.COM Article number 442.

27. Bernardi, M. (1975). Torino Storia ed Arte, Edizioni d'Arte Fratelli Pozzo, Torino, 1975.

28. Francesco Horologi, see details at http://www.museotorino.it/view/s/40ed93718b5943adaf3e6d $6 \mathrm{~b} 573 \mathrm{f} 4556$

29. At page 522 of The United Service Journal and Naval and Military Magazine, 1832, Part III, London, we can find the following : "The Citadel of Antwerp. (From personal inspection, by a Contributor to the United Service Journal.) This spot, on which the eye of all Europe is at present concentrated, lies at the southern extremity of Antwerp, and forms one continued line with its defences along the banks of the Scheldt. It is a regular pentagon in shape, protected by bastions ranging at progressive elevations, and connecting themselves with curtains of proportionate height. In advance of these defences are a further series of spacious bastions, immediately connected with the preceding, but of later construction. The one were erected by Paciotti and Cerbolini, two Italian engineers, by order of the tyrant Alba, 1568, and the others according to Vauban's principles in 1701.

30. The "Theatrum Sabaudiae" is the "Theatrum Statuum Regiae Celsitudinis Sabaudiae Ducis, Pedemontii Principis, Cypri Regis". It was an unprecedented publication having a promotional aim. It was the result of a project started by Charles Emmanuel II of Savoy in the 1660s, and ended in the 1680 s by Marie Jeanne Baptiste of Savoy-Nemours. It was published in 1682 in Amsterdam, by the editor Joan Blaeu. The Theatrum contains 145 engraved plates accompanied by descriptions in Latin describing towns and lands of the Duchy of Savoy.

31. Savorra, M.; Zucconi, G. (2010). Spazi e cultura militare nella città dell'Ottocento, Croma - Università Roma TRE. ISBN 10: 8883681118, ISBN13: 9788883681110

32. Vv. Aa. (2015). Goryokaku Castle, at http://wiki.samuraiarchives.com/index.php?title=Goryokaku_castle 


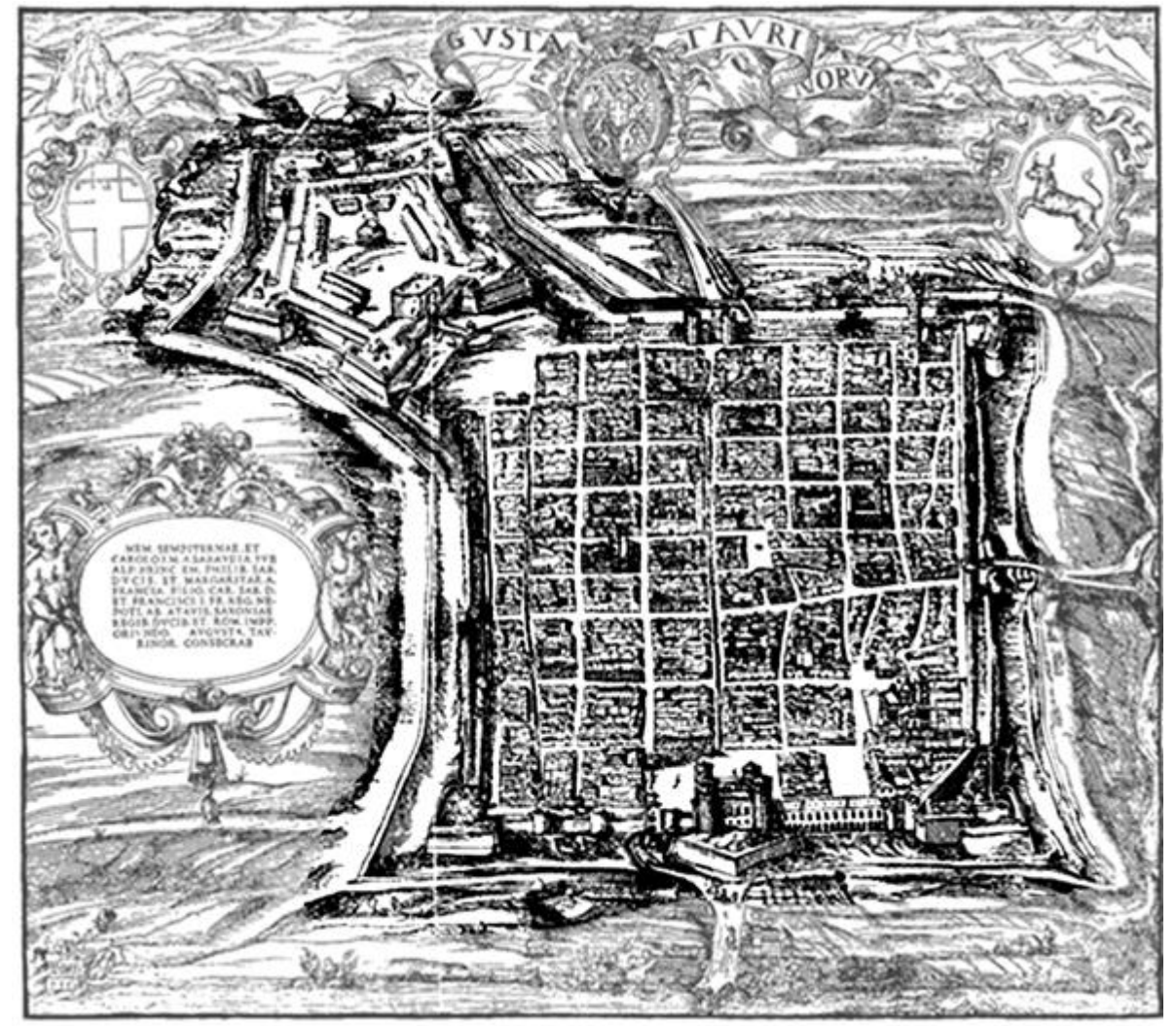

Figure 5: Torino in 1572, in a drawing by Giovanni Carracha (Jan Kraeck).

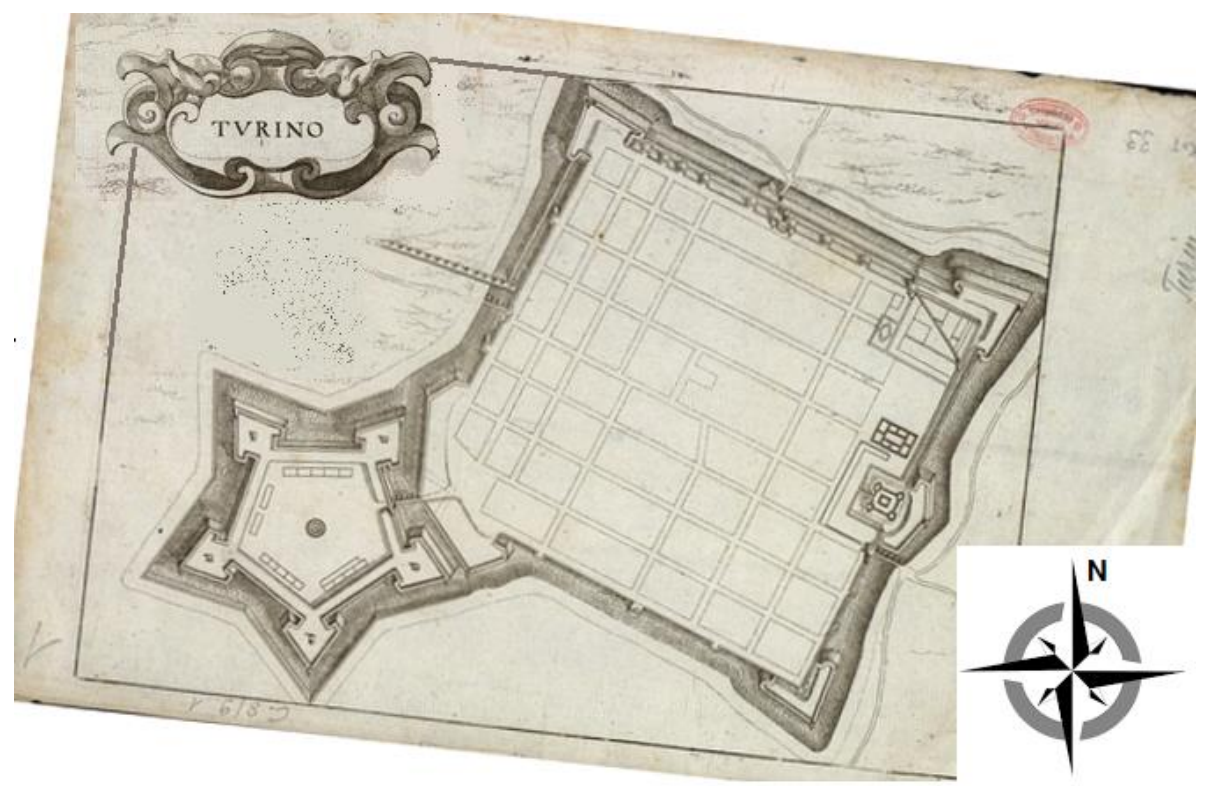

Martin Zeiller, Itinerarium Italiae, Frankfurt, M. Merian, 1640.

Figure 6: The Citadel of Turin in a map of 1640. The map had been rotated to have it oriented with cardinal directions of compass rose. 


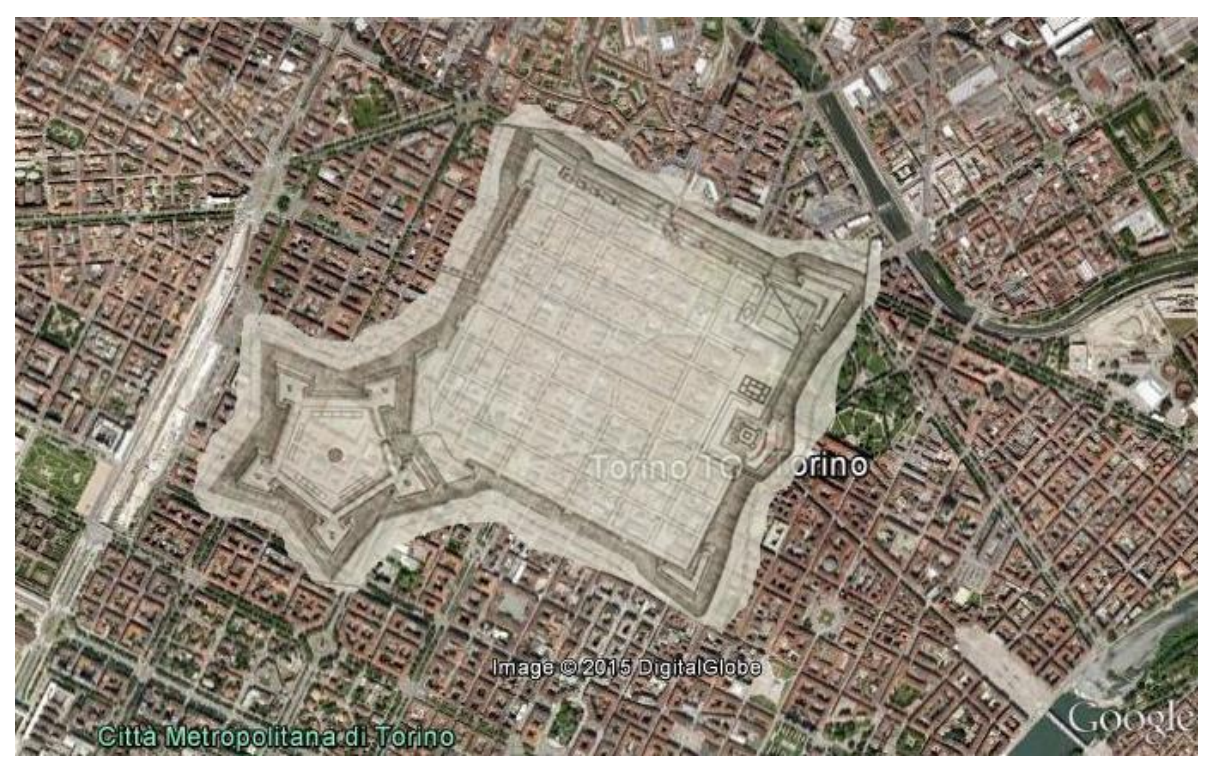

Figure 7: The map of Figure 6, on a Google Earth view of Turin.

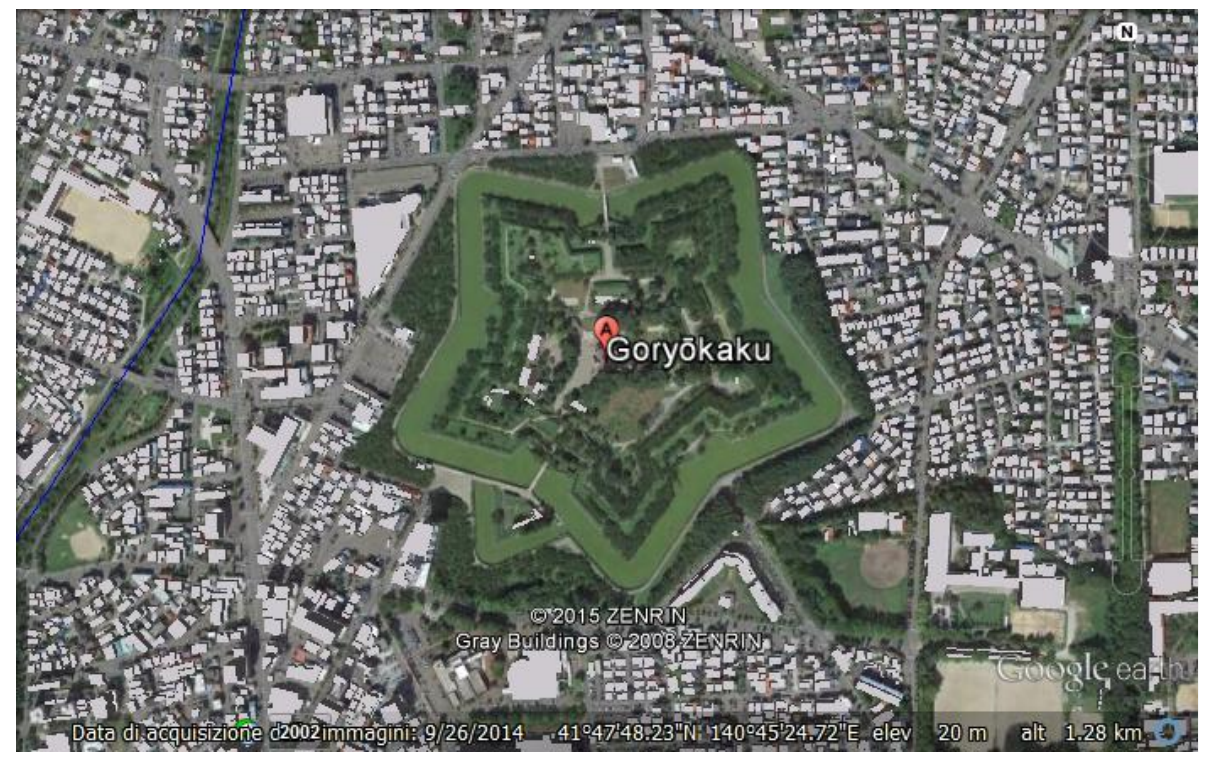

Figure 8: Goryokaku, the "five angle fortification", is a star fort in Japanese city of Hakodate on the island of Hokkaido. It has the same shape and orientation the Citadel of Turin had. 